\title{
DIVERSITY AND COMPARATIVE STUDIES ON BULINUS SNAILS COLLECTED FROM TWO LOCALITIES IN EGYPT BY
}

ABDEL HAKIM SAAD ${ }^{1}$, HANAA MOHAMED ABU EL EININ ${ }^{2}$, REWAIDA ABDEL-HAKEM ABDEL-GABER ${ }^{1}$ AND SHEREEN MAHFOUZ MANSOUR ${ }^{2^{*}}$ Department of Zoology ${ }^{1}$, Faculty of Science, Cairo University, Giza and Department of Environmental Research ${ }^{2}$, Theodor Bilharz Research Institute, Imbaba P. O. Box 30, Giza, Egypt ( ${ }^{*}$ Correspondence: E-mail: shery_83m@yahoo.com)

\section{Abstract}

A comparative study of the shell structure, seasonal temperature and Calcium content of Bulinus snails from two areas (Damietta and Giza) in Egypt was done and compared with laboratory snails from Schistosome Biological Supply Center (SBSC). The shells of collected snails identified as Bulinus truncatus, showed a wide variation in shape. The results showed a significant differences were detected between the populations from SBSC and Damietta $(p<0.05)$ for mean of measured shell width, aperture length, length of spire and number of whorls. The populations from Giza and Damietta governorates showed significant differences $(\mathrm{P}<0.05)$ in mean of measured length of diagonal, length of body whorl above aperture, length of spire and number of whorls. There were no statically significant differences between the populations from SBSC and Giza. The seasonal temperature affected on susceptibility of snails to infection with Schistosoma haematobium. The mean prepatent period was short in summer and long in winter. The shells of S. haematobium - infected B. truncatus snails showed hypocalcification from all localities.

Key words: Bulinus truncatus, Schistosoma haematobium, shell morphology, seasonal temperature, susceptibility, hypocalcification

\section{Introduction}

Planorbid freshwater snails that belong to the genus Bulinus act as the intermediate hosts for Schistosoma haematobium and related species. There are currently 37 species of Bulinus recognized (Brown, 1994), but the specificity of the snail parasite interaction is such that only certain species are involved in transmission of the parasite. ZeinEddine et al. (2014) recorded the distribution of Bulinus truncatus along River Nile and its branches.

Bulinus species possesses a sinistral shell and a pseudobranch (Yaseen, 1993). The Bulinus snail's shell shape varies widely. Variation occurs in the height of the spire, the form of the columellar margin and the size of the umbilicus. Mollusca shell is capable of modification in response to subtle differences in the environment (Bertness, 1980). On the basis of characteristics and morphometric analysis of shell (Brown et al., 1971a,b; Mimpfoundi and Ndassa, 2006) identified the population of B. tropicus or $B$. natalensis collected from crater lakes in the western mountainous volcanic region. Morphometric analysis showed that the ratio Length/Aperture length, with a low spire $(\mathrm{L} / \mathrm{AL}<1.45)$ and angular mesocones being associated with $B$. natalensis and populations with a high spire (L/AL>1.50) and non-angular mesocones to $B$. tropicus (Brown et al, 1971a, b).

The seasonal pattern is mainly governed by climatic factors, especially rain and temperature. The seasonal temperature variations are particularly important in bilharziasis-endemic areas with a subtropical climate, e.g. Egypt, Iran, South Africa (Pflüger et al, 1984). Water temperature is an important determinant of the limits of snail distribution and population size because egg production, hatching, maturation and death rates of juvenile and adult were all affected by the temperature (El-Hassan, 1974). Ittiprasert and Knight (2012) suggested that susceptibility of snails to infection is temperaturesensitive. The rate of cercarial maturation inside infected snails is also affected by temperature, increasing as temperature in- 
creases (Pflüger, 1980). Yousif et al. (1993) showed that longevity of infected snails, length of prepatent period of the parasite and duration of cercarial shedding are inversely proportional to the prevailing seasonal water temperature.

Calcium is a metal that exerts an essential role on the biology of the snails, once that, this ion is the main component of the snails shell, constituting an important limiting factor that determine the distribution and survival of the adult snails, oviposition rate, survival and development of eggs and the embryos (Davies and Erasmus, 1984). Freshwater snails obtain calcium from both the food and water (Mazuran et al, 1999). Mishkin and Jokinen (1986) reported that environmental calcium has positively effects on the fecundity and cercarial production of Biomophlaria glabrata infected with $S$. mansoni. The disturbance occurred in the metallic ion concentrations in the snails infected with trematode larva was considered as one of the causes of alterations occurred in the biological activities and the increase in the mortality of infected snails (Mahmoud et al, 2002; Mostafa, 2008; Mostafa and Bin Dajem, 2010; Mostafa et al, 2013).

The aim of this study was to identify Bulinus snails collected from two localities from Egypt based on morphological characters, relation between seasonal temperature and susceptibility (infection rate) of collected snails; in addition to determine the calcium content in the uninfected and infected shells and soft parts with trematode parasite.

\section{Materials and Methods}

The snails were collected by the method recommended by Mandahl-Barth (1962). Populations of Bulinus snails were collected from two Egyptian governorates (Giza and Damietta) and the $3^{\text {rd }}$ group was obtained from the Schistosome Biological Supply Center-Theodor Bilharz Research Institute (SBSC-TBRI) as a reference control.

Morphometric of Bulinus snail shell: Prior to measurements, the snail shells were cleaned in $10 \%$ oxalic acid using a tooth- brush to remove ferruginous deposits and foreign matter. All damaged shells, usually those with an incomplete apex, were removed from the samples. Measurements were made to the nearest $0.1 \mathrm{~mm}$ using vernier calipers according to the methods described by Kristensen et al. (1987). Variation was assessed for 9 characters: length (L); width (W); width of aperture (WA); aperture length (AL); width of shell at the level of the last suture (WS); length of diagonal (WD); length of body whorl above aperture (LH); length of spire (LS) (difference between length of shell and aperture) and number of whorls (NW). Spire length (L/AL), shell shape (L/W) and aperture shape (AL/AW) were calculated according to James (1968) in order to eliminate discrepancies resulting from size differences between individual samples. The recommended terms used by James (1968) and Gregoire (1972) to describe the latter three shell parameters are necessary to species.

Snail exposure and infection: The snails from each group were reared in the laboratory and their first generations (F1) were used throughout the infection experiment. Three replicates, each of 50 lab-bred sails $(4-6 \mathrm{~mm}$ in shell length), from each Governorate offspring were exposed individually to 10 newly hatched $S$. haematobium miracidia (SBSC-TBRI). After exposure, groups of the snails were maintained communally in plastic tray $(20 \times 30 \mathrm{~cm})$ containing 1.5 liters of aerated tap water and supplied with lettuce leaves, blue green algae. The water temperature was recorded weekly.

Starting from the day 21 post miracidial exposure, the snails were examined individually and repeatedly for cercarial shedding in multi dishes containing $2 \mathrm{ml}$ of dechlorinated tape water/ snail under artificial light for two hours (stimulated period). After initial shedding was observed, snails were screened individually once weekly till the death of snails. Infection rate, prepatent period, duration of cercarial shedding and cercarial production per snail per week were 
observed. The classification of snail's susceptibility to infection was dependent on the infection rate of the snail according to the method of Saoud (1965) in which snails were considered refractory below $10 \%$, low susceptible 10-25\%, moderate susceptible $25-50 \%$ and high susceptible at infection rate over $50 \%$.

Calcium content of Bulinus snails: Snails shedding cercariae and clean, non-exposed snails used as control (nearly of the same age and size of the shedding ones) from SBSC, Damietta and Giza groups were dissected in deionized water to separate soft parts from shells. Shells and soft parts were rinsed, at least, three times with deionized water. Excess water was removed from the shells and soft parts by using filter papers. Shells and soft tissues were grounded with mortar and pestle, pooled to achieve a weight of $500 \mathrm{mg}$ for each. Three pools of shells and soft parts from snails shedding cercariae and clean, non-exposed snails were prepared for analysis. Wet-weighted samples were digested in $10 \mathrm{ml}$ of concentrated nitric acid by boiling to dryness. The residue from each digested sample was diluted to $25 \mathrm{ml}$ with deionized water in a volumetric flask. Elemental analysis by flame atomic absorption spectrometry was performed to determine the calcium concentration. The flame wavelength and sample aspiration rate were optimized according to the manufacturer's recommendations, and four aqueous standards having analytic concentrations within the linear response range of the instrument and containing the same concentration of nitric acid as the samples were used for calibration. Each sample, standard and blank, was analyzed using three 10 -s integrations. The reagent blank was prepared, and its value was subtracted to give the final concentration. The final calcium concentration (C) was calculated according to the following equation:

$$
\mathrm{C}=\frac{\mathrm{F} \times \mathrm{V}}{\mathrm{WT} \times \mathbf{1 0 0 0}}
$$

Where $\mathrm{F}$ is the standard factor calculated from the standard curve, $\mathrm{V}$ is the volume of sample and WT is the wet weight of sample. Data are expressed in micrograms of calcium per gram of wet tissue or shell.

\section{Results}

The examination of the shell revealed that all specimens collected from Damietta, Giza governorates, in addition to those collected from Schistosome Biological Supply Center (SBSC) as control one, identified as Bulinus truncatus. The shell is sinistral and narrow shaped, varies in thickness from fragile, thin to rather thick. It is highly variable in shape from elongated ovate to conical or subconical. The whorls are spirally coiled and somewhat flattened. The whorls are generally convex and rounded at the periphery and are separated by a deep suture. The body whorl has horizontal or slightly concave border and developed shoulder. The spire is clearly shorter than the aperture and the apex varies from obtuse to rather elevated. The sculpture is more conspicuous on the body whorl than on earlier whorls. It includes thick transverse irregular ribs, furrows and rather coarse growth lines. The umbilicus is visible and varies from small to rather big. The aperture varies from elongate ovate to ovoid and almost round. It is limited by an outer convex lip and inner sharp columellar margin which leaves a small umbilicus between it and the surface of shell. The shell is without an operculum (Fig.1).

Comparison between linear measurements (Tab. 1) showed that the parameters of shells (Fig.2) from the studied sits presented variations. The significant differences were detected between the populations from SBSC and Damietta $(p<0.05)$ for mean of measured shell width $(\mathrm{W})$, aperture length $(\mathrm{AL})$, length of spire (LS) and number of whorls (NW). The populations from Giza and Damietta governorates showed significant differences $(\mathrm{P}<0.05)$ in mean of measured length of diagonal (WD), length of body whorl above aperture (LH), length of spire (LS) and number of whorls (NW). There were no 
statically significant differences between the

populations from SBSC and Giza in any measured character (Tab. 1).

Table 1: B. truncatus from Egypt, measurements of mean shell continuous characters.

\begin{tabular}{|c|c|c|c|}
\hline Shell characters & SBSC & Damietta & Giza \\
\hline L & $7.2 \pm 2.28^{\mathrm{a}}$ & $8.09 \pm 2.32^{\mathrm{a}}$ & $7.95 \pm 2.04^{\mathrm{a}}$ \\
\hline W & $4.66 \pm 1.33^{\mathrm{a}}$ & $5.69 \pm 1.44^{\mathrm{b}}$ & $5.47 \pm 1.29^{\mathrm{a}, \mathrm{b}}$ \\
\hline WA & $3.25 \pm 1.14^{\mathrm{a}}$ & $3.38 \pm 1.13^{\mathrm{a}}$ & $3.75 \pm 1.03^{\mathrm{a}}$ \\
\hline AL & $4.24 \pm 1.48^{\mathrm{a}}$ & $5.87 \pm 2.11^{\mathrm{b}}$ & $4.92 \pm 1.46^{\mathrm{a}, \mathrm{b}}$ \\
\hline WS & $1.65 \pm 0.56^{\mathrm{a}}$ & $1.42 \pm 0.56^{\mathrm{a}}$ & $1.7 \pm 0.50^{\mathrm{a}}$ \\
\hline WD & $3.27 \pm 0.93^{\mathrm{a}, \mathrm{b}}$ & $2.92 \pm 0.48^{\mathrm{b}}$ & $3.66 \pm 0.88^{\mathrm{a}}$ \\
\hline LH & $1.97 \pm 0.63^{\mathrm{a}, \mathrm{b}}$ & $1.73 \pm 0.37^{\mathrm{b}}$ & $2.32 \pm 0.67^{\mathrm{a}}$ \\
\hline LS & $2.96 \pm 0.91^{\mathrm{a}}$ & $2.22 \pm 0.38^{\mathrm{b}}$ & $3.03 \pm 0.87^{\mathrm{a}}$ \\
\hline NW & $3.25 \pm 0.55^{\mathrm{a}}$ & $2.8 \pm 0.29^{\mathrm{b}}$ & $3.15 \pm 0.32^{\mathrm{a}}$ \\
\hline
\end{tabular}

Data expressed as mean $\pm \mathrm{SD}$, number of snails for each tested group 21.

Means in same row, followed by different litters significantly different $(p<0.05)$.

Table 2: Calcium content $(\mathrm{M} \pm \mathrm{SD})$ in micrograms per gram of wet shells and soft parts of clean, nonexposed, and cercariae-shedding B. truncatus snail.

\begin{tabular}{|l|l|l|l|}
\hline Source & Snails & Shell of B. truncatus & Soft parts of B. truncatus \\
\hline \multirow{2}{*}{ SBSC } & Clean, nonexposed & $1003.8 \pm 199.1$ & $70.6 \pm 5.9$ \\
\cline { 2 - 4 } & Shedding & $489.72 \pm 90.59^{*}$ & $110 \pm 9.07^{* *}$ \\
\hline \multirow{2}{*}{ Damietta } & Clean, nonexposed & $1050 \pm 132.28$ & $72.33 \pm 3.77$ \\
\cline { 2 - 4 } & Shedding & $695.08 \pm 98.57^{*}$ & $85.8 \pm 10.1$ \\
\hline \multirow{2}{*}{ Giza } & Clean, nonexposed & $1066.7 \pm 144.89$ & $74.33 \pm 5.61$ \\
\cline { 2 - 4 } & Shedding & $726.83 \pm 150.41^{*}$ & $80.33 \pm 9.71$ \\
\hline
\end{tabular}

The shells showed a wide variation in shape which depend on certain characteristics namely: shell color, shape of the body whorl and certain conchological measurements. The morph from Giza, the shell varies in color from yellow to brownish. The body whorl is slightly rounded and moderate shoulder. The spire is medium, the mean $\mathrm{L} / \mathrm{AL}$ ratio was $1.63 \mathrm{~mm}$ and the aperture is wide, the mean AL/AW ratio was $1.32 \mathrm{~mm}$. Second form from Damietta, the shell varies in color from yellow to brownish. The body whorl is well rounded and shoulder is well developed. The spire is short and the calculated mean $\mathrm{L} / \mathrm{AL}$ ratio was $1.42 \mathrm{~mm}$. The aperture is very narrow and the calculated mean AL/WL ratio was $1.75 \mathrm{~mm}$. SBSC population form has yellow shell and the body whorl is slightly rounded and slightly shoulder. The spire is tall, the calculated mean L/AL ratio was $1.72 \mathrm{~mm}$ and the aperture is wide, the calculated mean AL/AW ratio was $1.33 \mathrm{~mm}$. This high correlation indicated that the calculated ration can be used with high reliability in predicting the length of different parts of the shell of $B$. truncatus from the shell length.

The offspring collected from SBSC, Damietta and Giza exposed to S. haematobium miracidia in summer and winter seasons and classification of snail's susceptibility according to infection rates. In summer (weekly mean temperature $25^{\circ} \mathrm{C}-29^{\circ} \mathrm{C}$ ), SBSC snails showed moderate susceptibility with infection rate, survival rate $\&$ mean number of cercariae/snail/week $(42.1 \%, \quad 76 \%, \quad 110 \pm$ 33.16; respectively). Damietta snails exhibited moderate susceptibility characters by infection rate, survival rate and mean number of cercariae/snail/week $(39.4 \%, 66 \%$, $47.5 \pm 20.2$; respectively). But, Giza snails showed low susceptibility with low infection rate, survival rate and mean number of cercariae/snail/week (17.85 \%, 56\%, 29.66 13.65; respectively). The duration of cercarial shedding was nearly similar in SBSC and Damietta snails $(3.3 \pm 1.0 \& 3.11 \pm 1.05)$ respectively but decreased in $\mathrm{G}(2.57 \pm 0.53)$. In winter season (weekly mean temperature $16^{\circ} \mathrm{C}-21^{\circ} \mathrm{C}$ ), the infection rate of SBSC 
snails was lower than summer season, and these snails exhibited moderate susceptibility with infection rate, survival rate and mean number of cercariae/snail/week (31\%, $58 \%, 88.75 \pm 30.1$; respectively). The susceptibility of Damietta snails to infection with S. haematobium was decreased significantly $(p<0.05)$ in winter in compared to summer. Snails were characterized by infection rate, survival rate and mean number of cercariae /snail/week (22.85\%, 70\% \& 41.66 \pm 22.86 ; respectively). Giza governorate showed low susceptibility with low infection rate, survival rate and mean number of cercariae/snail /week $(14.2 \%, 42 \% \& 20 \pm 7.54$; respectively). The duration of SBSC cercarial shedding snails $(2.63 \pm 0.8)$ followed by Damietta $(2.44 \pm 0.72)$ but decreased in Giza $(2.28 \pm$ 0.48 ). Prepatent period was nearly similar for all groups. The infection rate and mean number of cercariae/snail/week were higher in summer in compared to winter (Figs.3 A $\&$ B). The mean prepatent period was short in summer season and long in winter season.

Calcium content in the shells of clean, non-exposed $B$. truncatus was significant higher if compared with the calcium content in the shells of cercariae-shedding snails. In contrast, the calcium content in the soft parts of cercariae shedding snails was higher than in the soft part of clean, non-exposed snails, the difference was statistically significant $(p<0.01)$ in SBSC snails. Generally, calcium content was significantly higher in the shells than the soft parts of the snails, regardless were infected or non-infected (Tab. 2).

\section{Discussion}

Bulinus truncatus is one of the most common members of the freshwater snail fauna in Egypt, found most frequently along the margins and banks of small ponds with slow running or almost stagnate irrigation canals (Abd El-Wakeil et al, 2013). The present study showed that the populations of $B$. truncatus from Giza, Damietta and SBSC could be differentiated from morphometric characters. Conchological features proved to be useful in differentiating two populations of B. truncatus in Turkey (Sesen, 2004) and in Sudan (El Sheikh et al, 2010). Rollinson et al. (1998) managed to differentiate on morphologic basis B. africanus group from Lake Victoria. Presence of overlap in morphs among populations belonging to $B$. truncatus/tropicus complex from South Western Zimbabwe (Mukaratirwa et al, 1998) and among the B. africanus group from East Africa (Stothard et al, 1997).

The present results showed that the three populations are morphologically different, but Bulinus snails from Giza seems closely related to Bulinus snails from SBSC and both differ significantly from population sampled in Damietta. Yaseen (1993) found that a genetic difference in the chromosome numbers and karyotype of $B$. truncatus in Upper Egypt, this correlated to the morphological differentiation. According to shell attributes, the aothurs already came to the conclusion that Bulinus snails from Giza seemed to be closely related to B. truncatus in Upper Egypt (Yaseen, 1993) and Sudan (El Sheikh et al, 2010), but differences were found between populations in Sub-Saharan Africa (Nijokou et al, 2004; Zein-Eddine et al, 2014). The absence of migration from one site to another might favor the populations to evolve independently (Brown, 1994).

The dimensions recorded in the Damietta samples were close to those reported by Brown (1994) on the high-spired forms $(9.5 \times 6.5 \mathrm{~mm})$, but height of the spire is short $(\mathrm{L} / \mathrm{AL}=1.42)$ in comparison with the variation shown by B. truncatus/tropicus complex in south-eastern Africa (L/AL $>1.45$ ) (Brown et al,1994). The mean value L/AL of shells from Giza and SBSC was similar to mean values calculated by Mukaratirawa et al. (1998) on the samples from South Western Zimbabwe.

Temperature considered an important role and a key factor in determining schistosome transmission potential (Martens et al, 1997; Mangal et al, 2008; Allana et al, 2013; McCreesh and Mark Booth, 2013). The susceptibility of snails and cerarial output are 
important feature in the transmission patterns of schistosomiasis. These parameters are considerably affected by the prevailing temperature (Yousif et al, 1993). The temperature can act directly on disease by altering the susceptibility of hosts, the virulence of pathogens and the growth rates of both hosts and pathogens, which can in turn influence host pathology and disease emergence (Paull and Johnson, 2011).

The present results showed that the susceptibility (infection rate) and the mean number of cercariae/ snail/ week were higher in summer in compared to winter. In summer, SBSC and Damietta snails showed moderate susceptibility while Giza showed low susceptibility. In winter, SBSC snails showed moderate susceptibility while Damietta and Giza snails showed low susceptibility. This may be due to the snails exposed to high temperature had weaker immune defense, which potentially predisposes them to infections (Foster, 1964; Pflüger et al, 1984; Seppälä and Jokela, 2010; Aboelhadid et al, 2016) while at low temperature, cercarial development was slow or suspended, and the probability of cercariae maturing before the snails death (Pflüger, 1980; Kabatereine, et al, 2004).

The mean prepatent period was short in summer season and long in winter season. This result agreed with Yousif et al. (1993), who mentioned that the length of prepatent period of the parasite is inversely proportional to the prevailing seasonal water temperature. Mukaratirwa et al. (1996) explained the relation between prepatent period and parasite prevalence. Long prepatent periods are likely to generate low levels of prevalence, while short ones may lead to the majority of snails shed cercariae.

The calcium ion is one of the most important elements present in the shell of molluscs, mainly the gastropods. The calcium ion participates in many enzymatic reactions and is required to metabolic processes related to acid-basic equilibrium in the hemolymph (De With and Sminia, 1980). Moreo- ver, large amount of calcium are used in reproduction of the snails (Mazuran et al, 1999). Also, reduction in calcium concentration in water can reduce occurrence of snails in aquatic system (Young and Harris, 1974). In the present observation, calcium content was significantly higher in the shell than in the soft part of the snails, regardless infected or non-infected. This observation was correlated with that of White et al. (2005), who mentioned that under conditions of variable concentrations in the water and trematode parasitism, pulmonate snails are able to maintain a high concentration of $\mathrm{CaCO}_{3}$ in their shells.

The shells of $S$. haematobium-infected $B$. truncatus snails showed hypocalcification in the present study was agreed with Mostafa (2008) observed the hypocalcification in the Lymnea. natalensis infected with Fasciola gigantica. In the present study hypocalcification observed in the shells of $S$. haematobium infected $B$. truncatus snails may be due to that the snails used in this experiment were actively shedding cercariae snails. These cercariae utilized large amount of calcium, which may be compensated by calcium from the shell as suggested by Mostafa (2007). Davies (1983) revealed that the cercariae of $S$. mansoni sequester large amount of calcium in their pre-acetabular glands and such sequestration probably occurs at expense of calcium in the shell and hemolymph of the snail. In contrast the hypercalcification noted in the shells of E. lieiinfected $B$. alexandrina snails may be due to the E. liei cercariae within the snails' utilized small amount of calcium (Mostafa et al, 2013). Davies and Erasmus (1984) reported that $B$. glabrata containing larval stages of S. mansoni at 40 days post-infection showed disintegration of the calcium corpuscles in Type-A calcium cells and erosion of the inner surface of the shell.

In the present study, the soft parts of uninfected snails had decidedly less calcium than did those infected. This may be due to the presence of sporocysts containing cercariae 
and free cercariae that contained a large amount of calcium (Davies and Erasmus, 1984) in the tissues of infected snails. This result agreed with the observation of Layman et al. (1996). They reported that $\mathrm{Ca}$, $\mathrm{Cu}, \mathrm{Fe}, \mathrm{Na} \& \mathrm{Zn}$ were present in the digestive gland-gonad complex at higher concentration in infected as compared with uninfected snails. Furthermore, Ong et al. (2004) found significantly higher amount of $\mathrm{Ca}, \mathrm{Cd}$, $\mathrm{Mn} \& \mathrm{Na}$ in soft parts of B. glabrata infected with $S$. mansoni. These results were in contrast with Evans et al. (2001) and Bergey et al. (2002) in which infection decreased the amounts of certain elements in infected hosts.

\section{Conclusion}

The morphometric analysis proved to be a useful tool to distinguish between populations. The seasonal temperature and calcium content in the water effect on schistosomiasis transmission. The current work has concentrated on specific regions of Egypt and could add a significantly to the knowledge of $B$. truncatus which serves as the main intermediate host of $S$. haematobium in Egypt.

\section{Acknowledgments}

This research was kindly funded by the Internal Project. No. 93M, Theodor Bilharz Research Institute (TBRI).

\section{References}

Abd El-Wakeil, KF, Obuid-Allah, AH, Mohamed, AH, Abd El-Aziz, FA, 2013: Community structure of molluscans in River Nile and its branches in Assiut Governorate, Egypt. Egypt. J. Aquatic Res. 39:193-8.

Aboelhadid, SM, Thabet, M, El-Basel, D, Taha, R, 2016: Digenetic larvae in Schistosome snails from El Fayoum, Egypt with detection of Schistosoma mansoni in the snail by PCR. J. Parasit. Dis. 40, 3:730-4.

Allan, F, Dunn, AM, Emery, AM, Stothard, J R, Johnston, DA, et al, 2013: Use of sentinel snails for the detection of Schistosoma haematobium transmission on Zanzibar and observations on transmission patterns. Acta Trop.128:234-40.

Bergey, L, Weis, JS, Weis, P, 2002: Mercury uptake by the estuarine species Palaemonetes pugio and Fundulus heteroclitus compared with their parasites, Probopyrus pandalicola and Eustrongyloides sp. Mar. Pollut. Bull. 44:1046-50.

Bertness, MD, 1980: Growth and mortality in the ribbed mussel Geukensia demissa. Veliger 23:62-9.

Brown, DS, 1994: Freshwater Snails of Africa and Their Medical Importance, $2^{\text {nd }}$ revised edn. Taylor and Francis, London.

Brown, DS, Oberholzer, G, Van Eeden, JA, 1971a: The Bulinus natalensis/tropicus complex in southern Africa. 1. Shell, mantle, copulatory organ and chromosome number. Malacologia 11:141-70.

Brown, DS, Oberholzer, G.Van Eeden, JA, 1971b: The Bulinus natalensis/tropicus complex in south-eastern Africa. 2. Some biological observations, taxonomy and general discussion. Malacologia 11:171-98.

Davies, TW, 1983: Schistosoma mansoni: The structure and elemental composition of pre acetabular penetration gland cell secretion in preemergent cercariae. Parasitology, 87:55-60.

Davies, TW, Erasmus, DA, 1984: An ultrastructural study of the effect of parasitism by larval Schistosoma mansoni on the calcium reserves of the host, Biomphalaria glabrata. Cell Tissue Res., 236:643-649.

De With, ND, Sminia, T, 1980: The effects of the nutritional state and the external calcium concentration on the ionic composition of the hemolymph and on the calcium cells in the Pulmonate freshwater snail Lymnaea stagnalis. Proceed Koninklijke Nederlandse Akad. Wetensch. C 83:217-27.

El-Hassan, AA, 1974: Laboratory studies on the direct effect of temperature on Bulinus truncatus and Biomphalaria alexandrina, the snail intermediate hosts of schistosomes in Egypt. Folia Parasitol. 21:181-7.

El Sheikh, EB, Osman, EA, Mahmoud, ZN, 2010: Some linear Measurements of Bulinus truncatus Snails collected from Water Bodies of Two Agricultural Schemes in Khartoum State, Sudan. Uni. Afri. J. Sci.1:35-43.

Evans, DW, Irwin, SWB, Fitzpatric, S, 2001: The effect of Digenean (Platyhelminthes) infection on heavy metal concentration in Littorina littorea. J. Mar. Biol. Assoc. 81:349-50.

Foster, R, 1964: The effect of temperature on the development of Schistosoma mansoni Sambon 1907 in the intermediate host. J. Trop. Med. Hyg. 67:289-92. 
Gregorie, C, 1972: Structure of the Mollusca Shell. Academic Press, New York.

Ittiprasert, W, Knight, M, 2012: Reversing the resistance phenotype of the Biomphalaria glabrata snail host Schistosoma mansoni infection by temperature modulation. Plos. Pathol. 8, 4:16.

James, BL, 1968: The characters and distribution of the subspecies and varieties of littorina saxatalis (Olivi) in Britain. Cah. Biol. Mar. 9: 143-65.

Kabatereine, NB, et al., 2004: Epidemiology and geography of Schistosoma mansoni in Uganda: Implications for planning control. Trop. Med. Int. Hlth. 9:372-80.

Kristensen, TK, Frandsen, F, Christensen, $N$ O, 1987: Bulinus africanus/group snails in East and South East Africa, differentiated by use of biometric multivariate analysis on multivariate characters (Pulmonata:Planorbidae). Rev. Zool. Afri. 101:55-66.

Layman, LR, Dory, AC, Koehnlein, KM, Fried, B, Sherma, J, 1996: Effects of Echinostoma trivolvis (Trematoda) infection on metallic ions in the host snail Helisoma trivolvis (Gastropoda). Parasitol. Res. 82, 1:19-21.

Mahmoud, MB, El-Dafrawy, SM, El-Sayed, KA, EI-Din, AT, 2002: Effect of Echinostoma liei infection on alterations of protein content and some enzymes in Biomphalaria alexandrina snails. J. Egypt. Soc. Parasitol. 32, 2:361-72.

Mandahl-Barth, G, 1962: Key to the Identification of East and Central African Freshwater Snails of Medical and Veterinary Importance. Bull. WHO 27:135-50

Mangal, TD, Paterson, S, Fenton, A, 2008: Predicting the impact of long-term temperature changes on the epidemiology and control of schistosomiasis: A mechanistic model. Plos One 16 January, Research Article

Martens, WJM, Jetten, TH, Focks, DA, 1997: Sensitivity of malaria, schistosomiasis and dengue to global warming. Climatic Change, 35: 145-56.

Mazuran, N, Hrsak, M. Paes, D, 1999: Effects of $\mathrm{CaCl} 2$ and $\mathrm{CaBr} 2$ on the fecundity of Planorbarius corneus. Chemosphere 38:2345-55.

McCreesh, N, Booth, M, 2013: Challenges in predicting the effects of climate change on Schistosoma mansoni and Schistosoma haematobium transmission potential. Trends Parasitol. 29, 11:549-55.

Mimpfoundi, R, Ndassa, A, 2006: Morphologi- cal studies on Bulinus sp. (Gastropoda: Planorbidae) from Nchout Monoun, Cameroon. Afri. Zool. 41, 2:210-4.

Mishkin, EM, Jokinen, EH, 1986: Effect of environmental calcium on fecundity and cercarial production of Biomphalaria glabrata (Say) infected with Schistosoma mansoni Sambom. J. Parasitol. 72: 885-90.

Mostafa, SMO, 2007: Effects of Schistosoma mansoni and Schistosoma haematobium infections on calcium content in their intermediate hosts. Parasitol Res., 101:963-966.

Mostafa, SMO, 2008: Effect of Faciola gigantica experimental infection on some inorganic elements in the snail host Lymnaea natalensis. Exp. Parasitol. 118:468-71.

Mostafa, SMO, Bin Dajem, SM, 2010: Effects of Schistosoma mansoni experimental infection on some inorganic elements in the snail host $B i$ omphalaria alexandrina. J. Egypt. Soc. Parasitol. 40, 1:197-204.

Mostafa, SMO, Abu El-Eini, MH, Mosa, HA, 2013: In organic elements alteration in $B i-$ omphalaria alexandrina snails naturally parasitized with Echinostoma liei or Schistosoma mansoni. Sci. Int. 1, 5:139-43.

Mukaratirwa, S, Siegismund, HR, Kristensen, TK, Chandiwana, SK, 1996: Genetic structure and parasite compatibility of Bulinus globosus (Gastropoda: Planorbidae) from two areas of different endemicity of Schistosoma haematobi$u m$ in Zimbabwe. Int. J. Parasitol. 26, 3:269-80. Mukaratirwa, S, Kristensen, TK, Siegismund, HR, Chandiwana, SK, 1998: Genetic and morphological variation of populations belonging to the Bulinus truncatus/tropicus complex (gastropoda: Planorbidae) in south western Zimbabwe. J. Moll. Stud. 64:435-46.

Njiokou, F, Teukeng, E, Bilong Bilong, CF, Njine, T, Same Ekobo, A, 2004: Experimental study of the compatibility between Schistosoma haematobium and two species of Bulinus in Cameroon. Bull. Soc. Pathol. Exot. 97:43-6.

Ong, JH, Chejlava, M, Fried, B, Koehnlein, K M, Bosavage, GL, et al, 2004: Effects of Schistosoma mansoni infection on inorganic elements in the snail Biomphalaria glabrata. J. Helminthol. 78, 4:343-6.

Paull, SH, Johnson, PTJ, 2011: High temperature enhances host pathology in a snail-trematode system: possible consequences of climate change for the emergence of disease. Freshwater Biol. 56:767-78. 
Pflüger, W, 1980: Experimental epidemiology of schistosomiasis. I. The prepatent period and cercarial production of Schistosoma mansoni in Biomphalaria snails at various constant temperatures. Z. Parasitenkd. 63:159-69.

Pflüger, W, Roushdy, MZ El Emam, M, 1984: The prepatent period and cercarial production of Schistosoma haematobium in Bulinus truncatus (Egyptian field strains) at different constant temperatures. Z Parasitenkd, 70:95-103.

Rollinson, D, Stothard, J, Jones, CS, Lockyer, AE, de Souza, CP, et al, 1998: Molecular characterization of intermediate snail hosts and the search for resistance genes. Mem. Inst. Oswaldo Cruzonline 1:11-6.

Saoud, MFA, 1965: Comparative studies on the characteristics of some geographical strains of Schistosoma mansoni in mice and hamster. J. Helminthol. 39:101-12.

Sesen, R, 2004: A Study on the conchological features of two populations of Bulinus truncatus (Gastropoda: Pulmonata) in Turkey. Turk. J. Zool. 28:145-8.

Seppa"la“, O, Jokela, J, 2010: Immune defence under extreme ambient temperature. Biol. Lett. 7:119-22.

Stothard, JR, Mgeni, AF, Alawi, KS, Savioli, L, Rollinson, D, 1997: Observations on shell morphology, enzymes and random amplified polymorphic DNA (RAPD) in Bulinus africanus group snails (Gastropoda: Planorbidae) in Zanzibar. J. Moll. Stud. 63:489-503.

White, MM, Chejlava, M, Fried, B, Sherma, J, 2005: Effects of various larval digeneans on the calcium carbonate content of the shells of Helisoma trivolvis, Biomphalaria glabrata, and Physa sp. Parasitol. Res. 95, 4:252-5.

Yaseen, AE, 1993: Cytogenetics and Biology of the intermediate host of human Bilharziasis, $\mathrm{Bu}$ linus truncatus common in Upper Egypt. Cytologia 58:53-60.

Young, JO, Harris, JH, 1974: The occurrence of some invertebrate animals in the littoral zone of some low land lakes in Cheshire and Shropshire. Naturalist, 928:25-32.

Yousif, F, Roushdy, M, El Dafrawy, S, Shiff, C, 1993: Influence of seasonal temperature on the cercarial production of Schistosoma mansoni and Schistosoma haematobium in Egypt. J. Med. Appl. Malacol. 5:69-75.

Zein-Eddine, R, Félicité Flore Djuikwo-Teukeng, FF, Al-Jawhari, M, Senghor, B, Huyse, T, et al, 2014: Phylogeny of seven Bulinus species originating from endemic areas in three African countries, in relation to the human blood fluke Schistosoma haematobium. BMC Evol. Biol.14:271-83.

\section{Explanation of figures}

Fig. 1: Shells of B. truncatus from three different populations, each randomly chosen to show variation from population to population.

Fig. 2: Linear measurements of shell of B. truncatus used in discriminant analysis. Shell length (L); shell width (W); width of aperture (WA); aperture length (AL); width of shell at level of last suture (WS); length of diagonal (WD); length of body whorl above aperture (LH); length of spire (LS) (difference between length of shell and aperture) and number of whorls (NW).

Fig. 3: Seasonal variation of infection rate percent (A) and mean number of cercaria/snail/week (B) of snail B. truncatus collected from investigated sites of B. truncatus from Egypt. 

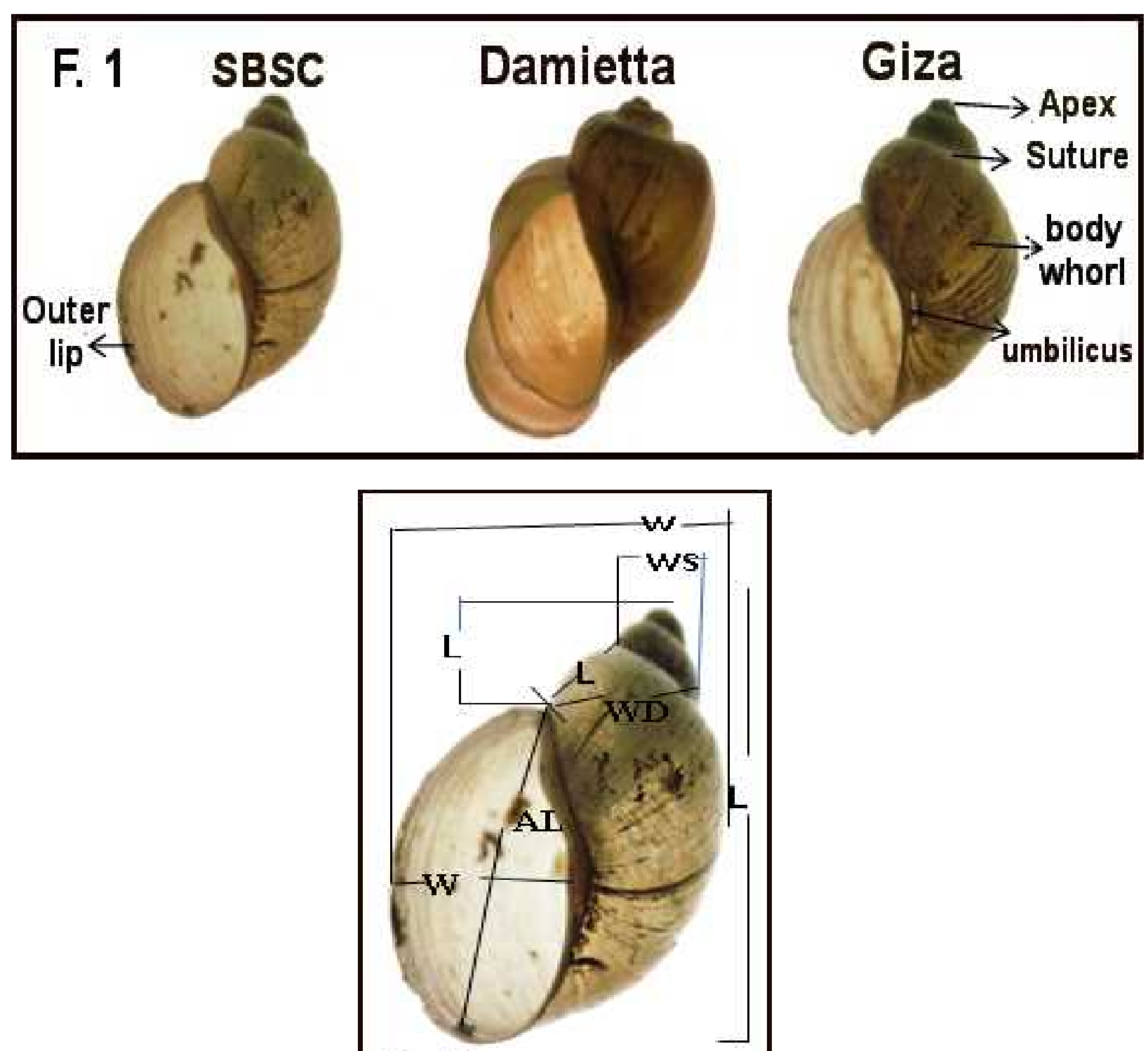

F. 2

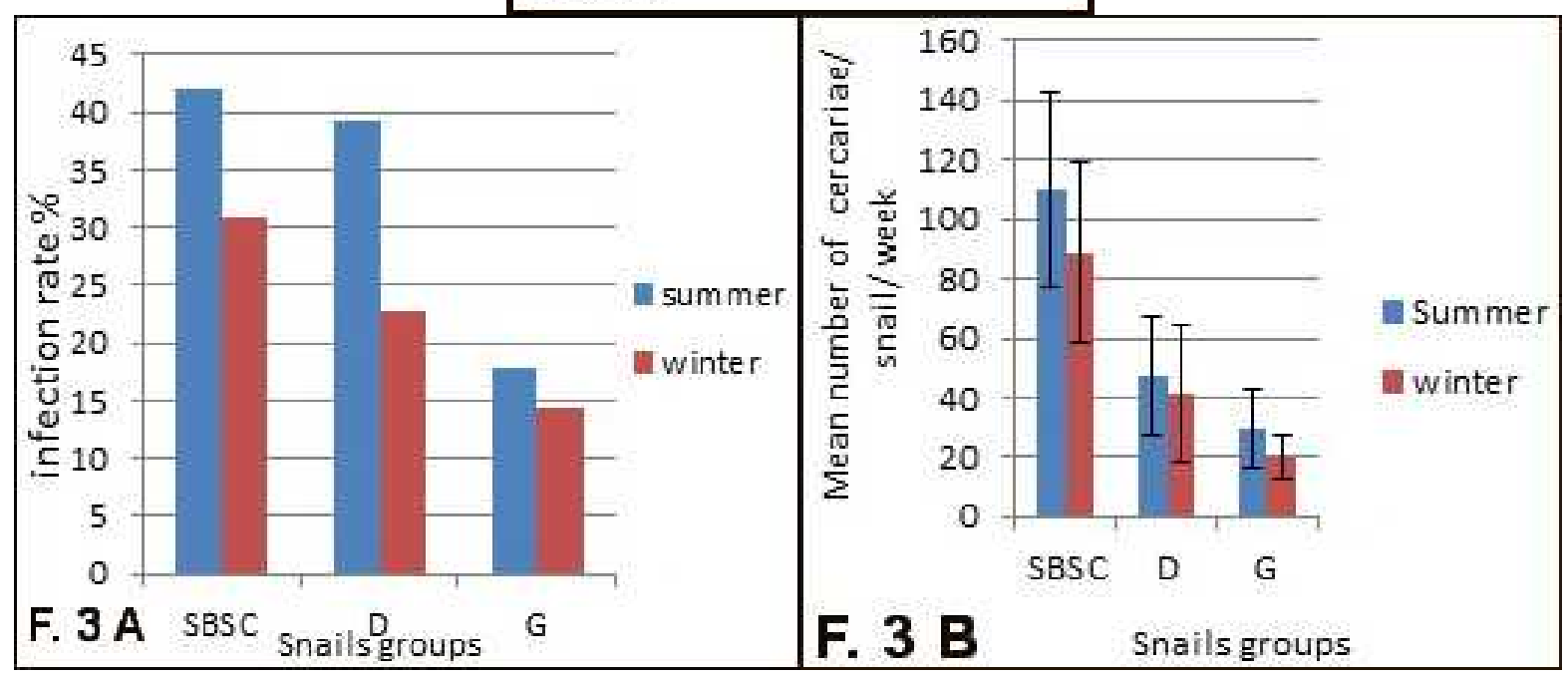

